\title{
Description of the Bacterium Causing Blight of Leek as Pseudomonas syringae pv. porri (pv. nov.)
}

\author{
R. Samson, H. Shafik, A. Benjama, and L. Gardan
}

First, second, and fourth authors: Institut National de la Recherche Agronomique, Centre d'Angers, Pathologie végétale et phytobactériologie, BP 57, 49071 Beaucouzé cedex, France; and third author: Institut National de la Recherche Agronomique, Station régionale de phytiatrie, BP 530, Marrakech, Morocco. Accepted for publication 7 May 1998.

\begin{abstract}
Samson, R., Shafik, H., Benjama, A., and Gardan, L. 1998. Description of the bacterium causing blight of leek as Pseudomonas syringae pv. porri (pv. nov.). Phytopathology 88:844-850.

Forty bacterial strains isolated from leek blight (Allium porrum) in France and other countries were studied by conventional biochemical methods, serological reactions, numerical taxonomy, DNA-DNA hybridization, and ice nucleation activity, as well as by pathogenicity on leek and other host plants. They were compared with reference strains of Pseudomonas, mainly pathotype strains of $P$. syringae pathovars and strains

tests (production of levan-sucrase, oxidase, pectinase, arginine dihydrolase, and hypersensitive reaction on tobacco). Leek strains were pathogenic to leek and produced symptoms identical to those observed in the field. They were the only strains in our study that could cause blight of leek. Thus, our results justify the creation of a new pathovar. Leek strains constituted a highly homogeneous DNA group and a discrete phenon by numerical taxonomy, and they belonged to O-serogroup POR. The name of $P$. syringae pv. porri is proposed for the bacterium causing leek blight. Criteria for routine identification are presented and taxonomic status is discussed.
\end{abstract} of $P$. syringae pv. syringae isolated from various host plants including onions. Leek strains sorted with $P$. syringae species (sensu lato) by LOPAT
Additional keywords: serology.
Bacterial blight of leek (Allium porrum) is a disease of both seedlings and seed crops and is reported in leek-production areas in Great Britain (17), France (24), New Zealand (13), the Netherlands (15), Italy (29), and very recently, the United States (16).

Leek bacterial blight appears as a foliar disease showing watery yellow lesions on young leaves leading to their typical curling and water-soaked, deep-green areas on flowering stems. The causal organism was first designated as Pseudomonas sp. by Lelliott (17) and then as $P$. syringae by Hale (13) after a brief description.

Preliminary studies concerned only the geographic distribution of leek blight in France, symptomatology, and the life cycle of the pathogen (24), as well as some identifying characteristics of the bacterium (23). A complete description of the pathogen was done to determine whether leek blight is due to an opportunistic and ubiquitous $P$. syringae strain or to a new pathovar. A pathovar (6) is an infrasubspecific term referring to a group of phytopathogenic bacteria principally on the basis of their host range. The purpose of this paper is to describe the leek blight pathogen using host range, numerical taxonomy, and DNA-DNA hybridization.

\section{MATERIALS AND METHODS}

Bacterial strains. From our and other laboratory collections, 40 leek (A. porrum) strains were selected as representative of the known geographical diversity of the leek blight agent (Table 1).

Leek strains were compared with 58 strains (including type strains and pathotype strains, designated by a superscript $\mathrm{T}$ after the collection number) of $P$. amygdali, $P$. cichorii, $P$. ficuserectae, $P$. savastanoi, $P$. syringae, and $P$. viridiflava obtained from the Collection Française de Bactéries Phytopathogènes (CFBP; Beau-

Corresponding author: R. Samson; E-mail address: samson@angers.inra.fr

Publication no. P-1998-0624-02R

(C) 1998 The American Phytopathological Society couzé, France). The type strain of each given species and pathovar (Fig. 1) was chosen according to published lists $(32,33,34)$. Additional strains were added to the sets of official reference strains on the basis of pathogenicity tests and serological reactions: $P$. syringae pv. berberidis, CFBP 3206 (=ICMP [International Collection of Microorganisms from Plants, Auckland, New Zealand] 4116); $P$. syringae pv. lachrymans, CFBP 1644 (=NCPPB [National Collection of Plant Pathogenic Bacteria, Harpenden, United Kingdom] 1096, Cucumis sativus, Hungary, 1957); P. syringae pv. morsprunorum, CFBP 2116 (Prunus cerasus, France, 1974); P. syringae pv. persicae, CFBP 1316 (Prunus persica, France, 1970); P. syringae pv. phaseolicola, CFBP 1882 (Phaseolus vulgaris, France, 1978); P. syringae pv. striafaciens, CFBP 1686 (=NCPPB 2480, Avena sativa, Zimbabwe, 1971); $P$. syringae pv. syringae, CFBP 1685 (=NCPPB 2264, Zea mays, Yugoslavia, 1965), CFBP 1764 (=ICMP 3189, Phaseolus vulgaris, New Zealand, 1971), CFBP 1767 (=NCPPB 2844, Triticum aestivum, United States, 1972), CFBP 1771 (=NCPPB 2691, Salix sp., New Zealand, 1968), and four strains isolated from $A$. cepa, CFBP 1787 (=NCPPB 2737), CFBP 2336, CFBP 2337, and CFBP 2338 received from Japan (M. Goto's 'a', '10', and '12', respectively); and P. syringae pv. tomato, CFBP 2545 (Lycopersicon esculentum, France, 1979) and CFBP 2546 (Lycopersicon esculentum, France, 1980).

Morphological, staining, and physiological testings. Colony morphology was described on yeast peptone dextrose agar (YPDA) (yeast extract, $3 \mathrm{~g} /$ liter; Biogelytone peptone [BioMérieux, Marcyl'Etoile, France], 5 g/liter; dextrose, 5 g/liter; and agar, 1.5 g/liter). Gram reaction was performed with $3 \% \mathrm{KOH}$ solution. Motility was determined by direct microscopic examination in broth. Growth was determined at 4 and $41^{\circ} \mathrm{C}$.

For conventional physiological characteristics $(19,27)$, bacteria were grown at $25^{\circ} \mathrm{C}$ and reactions were read after 4 days unless otherwise stated. Utilization of carbon sources was tested on ARJ mineral basal medium (1) $\left(\mathrm{NH}_{4} \mathrm{H}_{2} \mathrm{PO}_{4}, 1 \mathrm{~g} /\right.$ liter; $\mathrm{KCl}, 0.2 \mathrm{~g} /$ liter; $\mathrm{MgSO}_{4} .7 \mathrm{H}_{2} \mathrm{O}, 0.2 \mathrm{~g} /$ liter; agar, $3 \mathrm{~g} /$ liter, $\mathrm{pH} 6.8$; and bromothymol 
blue, $0.08 \mathrm{~g} /$ liter). Changes in the $\mathrm{pH}$ indicator were recorded daily for 2 weeks. Every test was replicated at least three times, with each strain using different batches of media and inocula.

Assimilation of 147 carbon sources (49 carbohydrates, 49 organic acids, and 49 amino acids) was studied with API-50 CH, $50 \mathrm{AO}$, and 50 AA galleries (BioMérieux), which were incubated at $25^{\circ} \mathrm{C}$. Growth was recorded after 6 days (8).

Numerical taxonomy. A total of 167 characteristics (147 carbon sources and 20 conventional biochemical tests: arginine dihydrolase; oxidase; gelatin; nitrate reduction; levan; fluorescence; hypersensitive reaction [HR] on tobacco; esculin; pectinolysis; Tween esterase; DNase; polypectate hydrolysis at $\mathrm{pH} 5$ and 8; and utilization of sucrose, lactate, L-(+)-tartrate, D-(-)-tartrate, erythritol, mannitol, and sorbitol in ARJ medium) were included in a data bank. A distance matrix was calculated using the Jaccard coefficient (28). Cluster analysis was done using the unweighted pair group method with averages.

The amount of information contributed by each criterion was measured by calculating the diagnostic ability coefficient (DAC). DAC is based on Baye's theorem using the occurrence of various diagnoses and on the information theory. It measures the quantity of information provided by each test (5). All calculations were done with the original TAXONUM program produced by G. Hunault (Faculté des Sciences, Angers, France) and L. Gardan.

Serological methods. Three antisera (S125, S135, and S136) were prepared by immunizing rabbits with bacterial whole-cell suspensions (26). Ouchterlony double diffusion was chosen because of its qualitative property (25) using concentrated bacterial suspensions $\left(10^{10} \mathrm{CFU} / \mathrm{ml}\right)$ grown in King's medium B for 2 days. For flagella serotyping, six antisera were used as described previously (12), namely antisera S223-2, S184-1, and S115-2 for the H1 serotype and S32, S183-2, and S191-2 for the H2 serotype. The position and number of flagella were also determined.

Pathogenicity tests. Leek strains, along with some other pathovar reference strains of $P$. syringae, were inoculated to a selected plant range including different Allium species and the pathovar differential hosts: tomato, bush bean, peach, pear, pea, cucumber, and lilac.

Leeks (A. porrum) cultivars Platina (Caillard, Les-Pouts-de-Cé, France) and Electra (Clause, Bretigny-sur-Orge, France) were grown in pots in greenhouse (temperatures 12 to $18^{\circ} \mathrm{C}$, no supplemental light regime) and field conditions. Plants were inoculated by spraying a bacterial suspension $\left(10^{8} \mathrm{CFU} / \mathrm{ml}\right)$ on young growing plants (three-leaf stage) and by infiltration with a syringe of three concentrations $\left(10^{2}, 10^{5}\right.$, and $10^{8} \mathrm{CFU} / \mathrm{ml}$ ) into the flower stem (five replicates). The following Allium species (vegetable or ornamental plants) were also inoculated: A. ampeloprasum, A. fistulosum (Welsh onion), and $A$. viviparum by stem infiltration; $A$. cepa (onion) and $A$. cepa var. aggregatum (shallot) by leaf spray and flower stem infiltration; $A$. sativum (garlic) and $A$. schoenoprasum by leaf infiltration; and A. giganteum and A. moly by leaf and stem infiltration.

Other known hosts of $P$. syringae pathovars were inoculated by the more convenient of two possible methods, plant organ infiltration and gentle spray: Lycopersicum esculentum (tomato cv. Montfavet 63-5) by spraying young leaves; Phaseolus vulgaris (French bean cv. Coco Nain Blanc) by leaf and pod infiltration; Prunus persica (peach tree seedlings cv. GF 305) by leaf and twig infiltration; Pyrus communis (pear tree seedlings cv. Fieudiere) by leaf infiltration; Pisum sativum (pea cv. Kelvedon Wonder) and Cucumis sativus (cucumber cv. Vert Long Maraicher) by spraying young plants; and Syringa vulgaris (Madame Lemoine clone) by leaf infiltration and leaf central vein injury. Negative controls were inoculated with sterile water. As positive controls, host plants were inoculated with homologous pathovars such as pv. tomato (CFBP 2546), pv. phaseolicola (CFBP 1882), pv. persicae (CFBP 1316), pv. syringae (strains from lilac, bean, peach, pear, and onion), pv. pisi $^{\mathrm{T}}$, and pv. lachrymans (CFBP 1644).
Ice nucleation activity (INA). After $24 \mathrm{~h}$ of growth on King's medium $\mathrm{B}$ at $16^{\circ} \mathrm{C}$, bacterial cells were suspended in $5 \mathrm{ml}$ of distilled water and adjusted to approximately $10^{9} \mathrm{CFU} / \mathrm{ml}$. Suspensions were then diluted 10 -fold in distilled water with five replicates. Dilutions were kept $1 \mathrm{~h}$ at $5^{\circ} \mathrm{C}$ before being placed in a refrigerated bath. Ice nucleating activity was tested by immersing the suspension tubes for $5 \mathrm{~min}$ at temperatures from -3 to $-9^{\circ} \mathrm{C}$ $(14,21)$.

DNA-DNA hybridizations. Bacterial DNA was extracted and purified according to Brenner et al. (2). Native DNA was labeled in vitro by nicktranslation with ${ }^{3} \mathrm{H}$-labeled nucleotides (Amersham International, Amersham, United Kingdom). The hybridization experiment used the $\mathrm{S} 1$ nuclease procedure described by Crosa et al. (3). Sheared, labeled, single-stranded test DNA (from the leek pathogen CFBP 1908) and sheared, unlabeled, single-stranded DNA in a $1: 1,500$ ratio were mixed in $0.42 \mathrm{M} \mathrm{NaCl}$ and incubated at $70^{\circ} \mathrm{C}$ for $16 \mathrm{~h}$. Single-stranded DNA fragments could be specifically hydrolyzed by $\mathrm{S} 1$ endonuclease. The reassociated DNA could be separated from nucleotides (hydrolysis products) by precipitation with cold trichloroacetic acid and collection of precipitate by cellulose nitrate membranes $(0.45 \mu \mathrm{m})$. The binding ratio was obtained by dividing the $\mathrm{S} 1$-treated sample by the untreated sample. The experiments were repeated twice.

TABLE 1. Origin of the bacteria isolated from leek (Allium porrum)

\begin{tabular}{|c|c|c|c|}
\hline $\begin{array}{l}\text { Strain } \\
\text { CFBP }^{a} \text { number }\end{array}$ & Country (area) & Isolator & $\begin{array}{l}\text { Year of } \\
\text { isolation }\end{array}$ \\
\hline $752 *$ & France (Lot et Garonne) & J. P. Prunier & 1964 \\
\hline $1687^{*}=\mathrm{NCPPB}^{\mathrm{b}} 268$ & United Kingdom & W. J. Dowson & 1949 \\
\hline $1770^{*}=\mathrm{ICMP}^{\mathrm{c}} 3644$ & New Zealand & C. N. Hale & 1973 \\
\hline $1907 *$ & France (Loire atlantique) & R. Samson & 1978 \\
\hline $1908 *$ & France (Loire atlantique) & R. Samson & 1978 \\
\hline $1909^{*}$ & France (Loire atlantique) & R. Samson & 1978 \\
\hline 1910 & France (Indre et Loire) & R. Samson & 1978 \\
\hline $1911^{*}$ & France (Haute Garonne) & R. Samson & 1975 \\
\hline $1912 *$ & France (Loire et Cher) & R. Samson & 1979 \\
\hline $1913 *$ & France (Maine et Loire) & R. Samson & 1979 \\
\hline 1956 & France (Vienne) & B. Rat & 1975 \\
\hline $2360 *$ & France (Gers) & R. Samson & 1980 \\
\hline $2361 *$ & France (Aude) & R. Samson & 1980 \\
\hline $2362 *$ & France (Pyrénées atlantiques) & R. Samson & 1980 \\
\hline $2363^{*}$ & France (Manche) & R. Samson & 1980 \\
\hline $2364 *$ & France (Ille et Vilaine) & R. Samson & 1981 \\
\hline $2365^{*}$ & France (Dordogne) & R. Samson & 1981 \\
\hline $2366^{*}$ & France (Nord) & R. Samson & 1981 \\
\hline $2367 *$ & France (Lot et Garonne) & R. Samson & 1982 \\
\hline $2368 *$ & France (Tarn) & J. F. Chauveau & 1984 \\
\hline $2369^{*}$ & France (Cher) & R. Samson & 1984 \\
\hline $2395^{*}=\mathrm{P} 1$ & Italy & L. Varvaro & 1983 \\
\hline $2396^{*}=\mathrm{P} 6$ & Italy & L. Varvaro & 1983 \\
\hline 2397 & France & J. F. Chauveau & 1984 \\
\hline 2451 & France & J. F. Chauveau & 1984 \\
\hline $2474^{*}=\mathrm{PD}^{\mathrm{d}} 341$ & The Netherlands & J. Janse & 1981 \\
\hline $2475^{*}=\mathrm{PD} 347$ & The Netherlands & J. Janse & 1981 \\
\hline $2476^{*}=\mathrm{PD} 354$ & The Netherlands & J. Janse & 1981 \\
\hline $2505^{*}=\mathrm{PD} 415$ & The Netherlands & J. Janse & 1982 \\
\hline $2506^{*}=\mathrm{PD} 371$ & The Netherlands & J. Janse & 1982 \\
\hline $4235^{*}$ & France (Pyrénées atlantiques) & R. Samson & 1980 \\
\hline SE29-1 & France (Lot et Garonne) & R. Samson & 1985 \\
\hline SE80-2 & France (Deux Sévres) & R. Samson & 1985 \\
\hline $4236^{*}=82-12-15$ & United States (California) & R. Campbell & 1988 \\
\hline 4237 & France & M. Guenard & 1989 \\
\hline 4238 & France & M. Guenard & 1989 \\
\hline $4239=\mathrm{B} 1$ & Spain & C. Noval & 1993 \\
\hline $4240=\mathrm{B} 2$ & Spain & C. Noval & 1993 \\
\hline 4241 & Canada (Quebec) & R. Samson & 1993 \\
\hline 4242 & France (Ain) & R. Samson & 1994 \\
\hline
\end{tabular}

${ }^{a}$ Collection Francaise de Bacteries Phytopathogenes, Angers, France. * $=$ Strains included in the numerical taxonomic study.

b National Collection of Plant Pathogenic Bacteria, Harpenden, United Kingdom.

c International Collection of Microorganisms from Plants, Auckland, New Zealand.

${ }^{\mathrm{d}}$ Plantenziektenkundige Dienst, Wageningen, the Netherlands. 


\section{RESULTS}

Genus and species identification of the leek strains. Leek strains were Gram-negative rods, motile by two flagella of the serotype H1. On YPDA plates, the colonies appeared creamy and semitranslucent and had undulate margins and a diameter of 1.2 to $1.5 \mathrm{~mm}$ within 3 days. Cultures produced a brown diffusible pigment on YPDA agar. Their growth was slower on King's medium B, where they formed small star-shaped colonies after 3 days. All but one strain produced a green fluorescent pigment on King's medium B. They were obligate aerobes and oxidized glucose. Growth factors were not required, since they were able to grow on minimal medium with glucose. Growth occurred at $4^{\circ} \mathrm{C}$, but not at $41^{\circ} \mathrm{C}$. They were oxidase negative, arginine dihydrolase negative, and gave a typical HR on tobacco leaves. These characteristics lead to the assignment of this bacterium to the species $P$. syringae sensu lato (20).

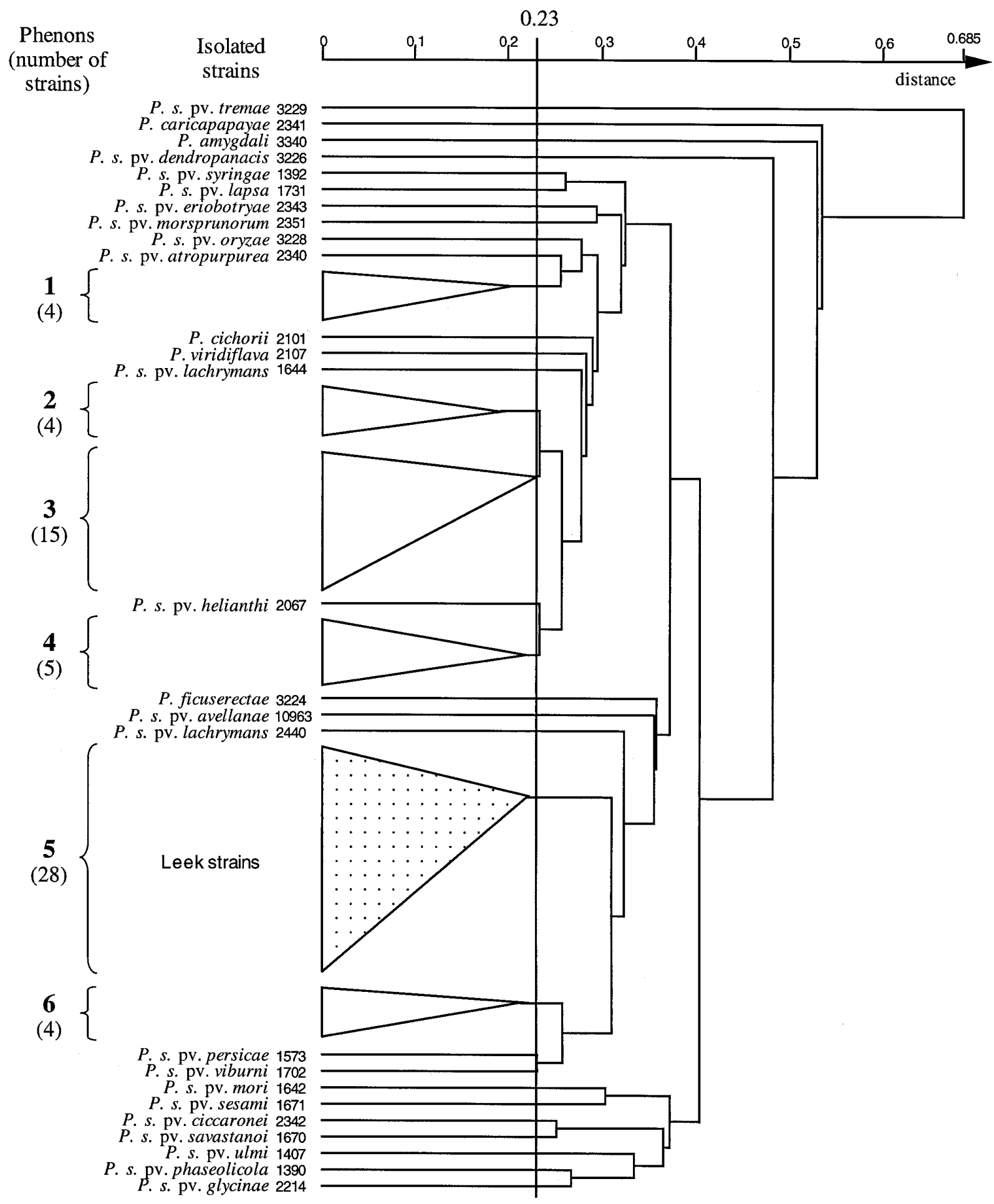

Fig. 1. Dendrogram of the distances among 28 leek strains and 58 strains of Pseudomonas syringae pathovars and related bacteria tested for 167 physiological characteristics. Phenon 1: P. syringae pvs. coronafaciens $2216^{\mathrm{T}}$, garcae $1634^{\mathrm{T}}$, and striafaciens $1674^{\mathrm{T}}$ and 1686 ; Phenon 2 : P. syringae pvs. delphinii $2215^{\mathrm{T}}$, hibisci $2895^{\mathrm{T}}$, morsprunorum 2116, and passiflorae $2346^{\mathrm{T}}$; Phenon 3: P. syringae pvs. aceris $2339^{\mathrm{T}}$, apii $2103^{\mathrm{T}}$, aptata $1617^{\mathrm{T}}$, atrofaciens $2213^{\mathrm{T}}$, dysoxyli $2356^{\mathrm{T}}$, japonica $2896^{\mathrm{T}}$, maculicola $1657^{\mathrm{T}}$, mellea $2344^{\mathrm{T}}$, panici $2345^{\mathrm{T}}$, papulans $1754^{\mathrm{T}}$, pisi $2105^{\mathrm{T}}$, primulae $1660^{\mathrm{T}}$, ribicola $2348^{\mathrm{T}}$, tabaci $2106^{\mathrm{T}}$, and tomato $2212^{\mathrm{T}}$; Phenon 4: P. syringae pvs. aesculi $2894^{\mathrm{T}}$, myricae $2897^{\mathrm{T}}$, photiniae $2899^{\mathrm{T}}$, tagetis $1694^{\mathrm{T}}$, and theae $2353^{\mathrm{T}}$; Phenon 5 : 28 leek strains (pv. porri); and Phenon 6: P. syringae pvs. anthirrini $1620^{\mathrm{T}}$, berberidis $1727^{\mathrm{T}}$ and 3206 , and philadelphi $2898^{\mathrm{T}}$. 
Pathogenicity. Typical symptoms of greasy blight were reproduced by leek strains when inoculated on leeks. Greasy stripes were produced when bacteria were either injected into leaves or sprayed on young plants in a nursery. Deep-green lesions on the flowering stems were easily produced by injecting bacteria with a syringe. Flowering stem inoculation was chosen to compare virulence of the strains (Fig. 2). For the most aggressive strain, an inoculum concentration of $10^{2}$ cells per $\mathrm{ml}$ was sufficient to induce the disease (Table 2).

Leek strains were only pathogenic to leek, since no symptoms appeared when they were inoculated to the five other Allium species or to the seven other plant species listed in Materials and Methods. In comparison, typical symptoms were obtained with reference pathovars on their homologous hosts: $P$. syringae pv. phaseolicola (CFBP 1882) on bean, pv. tomato (CFBP 2546) on tomato, pv. pisi $^{\mathrm{T}}$ on pea, and pv. lachrymans (CFBP 1644) on cucumber. Suspensions containing $10^{8} \mathrm{CFU}$ of leek strains per ml induced HRs on the Allium species other than A. porrum, as well as on bush bean, peach, and pear leaves. When inoculated to leek, none of the aforementioned pathovars of $P$. syringae tested (pv. phaseolicola, tomato, pisi, lachrymans, and syringae isolated from bean, peach, pear, and onion, respectively) caused a typical watery blight.

Finally, out of 50 strains of other pathovars inoculated to leek, 32 strains induced a HR, 16 strains gave no reaction, and two strains induced slight hyperplasia (Table 3). The HR responses on leek quickly became sunken and white, in contrast with the compatible reaction that gave water-soaked leaf stripes or stem spots (Fig. 2), which developed slowly and enlarged with time.

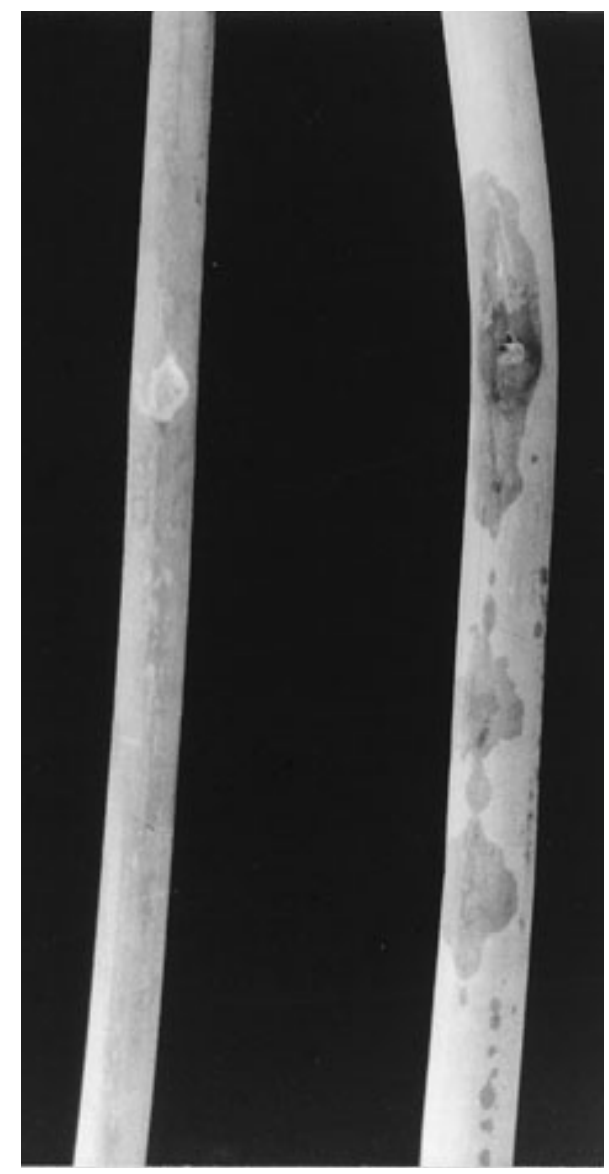

Fig. 2. Symptoms on leek flower stem. Left: Hypersensitive reaction induced by each of 25 pathovars of Pseudomonas syringae. Right: Typical watersoaked lesions induced by Pseudomonas syringae pv. porri. Leek flower stems were inoculated by injecting a suspension of $10^{8}$ bacteria per $\mathrm{ml}$ under the epidermis with a syringe.
DNA relatedness. The nine leek strains tested were 81 to $100 \%$ related to leek reference strain CFBP 1908 (Table 4). The reference strains of $P$. syringae pv. syringae (CFBP $\left.1392^{\mathrm{T}}\right)$, $P$. syringae pv. tomato (CFBP $2212^{\mathrm{T}}$ ), and P. savastanoi $\left(\mathrm{CFBP} 1670^{\mathrm{T}}\right)$ were 45,53 , and $48 \%$ related to CFBP 1908, respectively. Thus, leek strains constituted a highly homogeneous DNA group, distinct from $P$. syringae and $P$. savastanoi.

Numerical analysis. The dendrogram displaying the distance relationships among the 86 strains studied is shown in Figure 1. At a distance of 0.23 , the 28 strains studied (Table 1) and isolated from leek were clustered in a same phenon (phenon 5). A phenon corresponds to a group of strains exhibiting common phenotypical characteristics. Five additional phenons and 26 isolated phenotypes were observed (Table 1). Thus, leek strains constituted a discrete phenon. Based on their DAC, nine carbon sources delineated phenon 5 (Table 5).

INA. The ice nucleation ability was tested during a survey on the occurrence of the disease in Loire Valley, France, and was performed on 78 leek isolates. None of the strains was INA positive at $-2^{\circ} \mathrm{C}$, but 64 strains $(82 \%)$ were INA positive at $-5^{\circ} \mathrm{C}$.

Serological reaction. Ouchterlony double diffusion gave, in $24 \mathrm{~h}$, one thick and rather diffused band, typical of O-antigen recognition. All leek strains (except CFBP 4235) reacted with the three antisera and belonged to O-serogroup POR (26). The exception was strain 4235, which belonged to O-serogroup RIB, which contains rough type cultures. When strain 4235 was inoculated on leek, it gave typical watery blight. Bacteria reisolated from the lesions still typed as serogroup RIB.

The majority of the $P$. syringae pathovars gave no serological reaction at all. However, three groups of strains showed cross-reactions with leek strains (Table 6). A group including $P$. syringae pv. coronafaciens $^{\mathrm{T}}$ and some strains of $P$. syringae pv. syringae (1685, 1767 , and 1771) revealed partial identity with leek strains as shown by a spur. This group belonged to O-serogroup SYR2. A second group composed of $P$. syringae pv. atropurpurea ${ }^{\mathrm{T}}, P$. syringae $\mathrm{pv}$. cannabina $^{\mathrm{T}}, P$. syringae pv. garcae $^{\mathrm{T}}, P$. syringae $\mathrm{pv}$. papulans ${ }^{\mathrm{T}}, P$. syringae pv. syringae strains (the type strain CFBP $1392^{\mathrm{T}}$ and CFBP 1764), and P. syringae pv. tomato CFBP 2545, belonging to PERSAVTOM2, gave partial identity distinct from the first one. Finally, P. syringae pv. viburni ${ }^{\mathrm{T}}$, the four onion strains (CFBP 1787, CFBP 2336, CFBP 2337, CFBP 2338) from Japan, and P. syringae pv. delphinii ${ }^{\mathrm{T}}$, belonging to $\mathrm{O}$-serogroup DEL, formed a third group that exhibited no strong consistent reactions except for a faint spur in some tests.

Physiological profiles. Conventional biochemical characteristics were investigated to determine tests to differentiate leek strains from serologically and taxonomically related pseudomonads (Table 6). The main differential criteria for leek strains were hydrolysis of gelatin (weak and slow); no hydrolysis of casein, esculin, or pH 5 polypectate; production of melanins from tyrosine; no utilization of inositol; and utilization of homoserine. The onion strains from Japan were clearly different from leek pathogens by their inability to utilize mannose and homoserine.

TABLE 2. Infection incidence (\%) at different bacterial concentrations for 19 leek strains inoculated into leek flower stems

\begin{tabular}{lcrr}
\hline & \multicolumn{3}{c}{ Inoculum concentration ${ }^{\mathrm{a}}$ (bacteria per $\mathrm{ml}$ ) } \\
\cline { 2 - 4 } CFBP number & $10^{8}$ & $10^{5}$ & $10^{2}$ \\
\hline 1687 & $100^{\mathrm{b}}$ & 100 & 100 \\
1908 & 100 & 20 & 20 \\
$752,1907,1913,2366$ & 100 & 100 & 0 \\
$1911,1912,2362,2369$ & 100 & 80 & 0 \\
$1770,1956,2360$ & 100 & 60 & 0 \\
$1910,2361,2363,2365,2367$ & 100 & 20 & 0 \\
2364 & 100 & 0 & 0 \\
\hline
\end{tabular}

${ }^{a}$ Injection of $20 \mu \mathrm{l}$ of bacterial suspension with a syringe under the flower stem epidermis.

b Percentage of water-soaked stems 13 days after inoculation (five replicates). 


\section{DISCUSSION}

The leek blight strains belong to group I of fluorescent pseudomonads (18), which constitutes the $P$. syringae species sensu lato (20). Although leek strains were collected for the current study from eight different countries, they appeared to constitute a very homogeneous group. They showed a single profile of biochemical and physiological characters. All the strains were clustered in a separate phenon when the results of phenotypical tests were analyzed by numerical taxonomy. This analysis included 58 other Pseudomonas strains representing six species and 49 pathovars of $P$. syringae. All but one rough strain belonged to O-serogroup POR. Furthermore, leek strains induced a typical watery blight of parenchyma cells on leek leaves and flower stems, in contrast to all of the other

TABLE 3. Symptoms produced by 38 different pathovars of Pseudomonas syringae on leek ${ }^{\mathrm{a}}$

\begin{tabular}{|c|c|c|c|c|}
\hline \multirow[b]{2}{*}{ Pathovarb } & \multicolumn{4}{|c|}{ Symptoms } \\
\hline & $\begin{array}{l}\text { Hypersensitive } \\
\text { reaction }\end{array}$ & $\begin{array}{c}\text { No } \\
\text { reaction }\end{array}$ & $\begin{array}{c}\text { Light } \\
\text { hyperplasia }\end{array}$ & $\begin{array}{l}\text { Water- } \\
\text { soaking }\end{array}$ \\
\hline aceris $^{\mathrm{T}}$ & $\mathrm{X}$ & & & \\
\hline anthirrini ${ }^{\mathrm{T}}$ & $\mathrm{X}$ & & & \\
\hline$a p i i^{\mathrm{T}}$ & $\mathrm{X}$ & & & \\
\hline aptata $^{\mathrm{T}}$ & $\mathrm{X}$ & & & \\
\hline atrofaciens ${ }^{\mathrm{T}}$ & $\mathrm{X}$ & & & \\
\hline atropurpurea $^{\mathrm{T}}$ & $\mathrm{X}$ & & & \\
\hline berberidis $^{\mathrm{T}}$ & $\mathrm{X}$ & & & \\
\hline cannabina ${ }^{\mathrm{T}}$ & & $\mathrm{X}$ & & \\
\hline ciccarone $^{\mathrm{T}}$ & & $\mathrm{X}$ & & \\
\hline coronafaciens $^{\mathrm{T}}$ & $\mathrm{X}$ & & & \\
\hline delphinii $^{\mathrm{T}}$ & $\mathrm{X}$ & & & \\
\hline eriobotryae $^{\mathrm{T}}$ & $\mathrm{X}$ & & & \\
\hline garcae $^{\mathrm{T}}$ & $\mathrm{X}$ & & & \\
\hline glycinea $^{\mathrm{T}}$ & $\mathrm{X}$ & & & \\
\hline helianthi $^{\mathrm{T}}$ & & $\mathrm{X}$ & & \\
\hline lachrymans $^{\mathrm{T}}$ & & $\mathrm{X}$ & & \\
\hline 1644 & & $\mathrm{X}$ & & \\
\hline lapsa $^{\mathrm{T}}$ & $\mathrm{X}$ & & & \\
\hline leek strains (40 strains) & & & & $\mathrm{X}$ \\
\hline maculicola ${ }^{\mathrm{T}}$ & $\mathrm{X}$ & & & \\
\hline mellea $^{\mathrm{T}}$ & $\mathrm{X}$ & & & \\
\hline mori $^{\mathrm{T}}$ & & $\mathrm{X}$ & & \\
\hline morsprunorum $^{\mathrm{T}}$ & & $\mathrm{X}$ & & \\
\hline panici $^{\mathrm{T}}$ & $\mathrm{X}$ & & & \\
\hline papulans $^{\mathrm{T}}$ & & & $\mathrm{X}$ & \\
\hline passiflorae ${ }^{\mathrm{T}}$ & $\mathrm{X}$ & & & \\
\hline persicae 1316 & & & $\mathrm{X}$ & \\
\hline persicae $^{\mathrm{T}}$ & & $\mathrm{X}$ & & \\
\hline phaseolicola $^{\mathrm{T}}$ & & $\mathrm{X}$ & & \\
\hline 1888 & & $\mathrm{X}$ & & \\
\hline$p i s i^{\mathrm{T}}$ & $\mathrm{X}$ & & & \\
\hline primulae $^{\mathrm{T}}$ & $\mathrm{X}$ & & & \\
\hline ribicola ${ }^{\mathrm{T}}$ & & $\mathrm{X}$ & & \\
\hline savastanoi $^{\mathrm{T}}$ & & $\mathrm{X}$ & & \\
\hline $\operatorname{sesami}^{\mathrm{T}}$ & & $\mathrm{X}$ & & \\
\hline striafaciens $^{\mathrm{T}}$ & $\mathrm{X}$ & & & \\
\hline syringae $^{\mathrm{T}}$ & $\mathrm{X}$ & & & \\
\hline 1685 (maize) & $\mathrm{X}$ & & & \\
\hline 1764 (bean) & $\mathrm{X}$ & & & \\
\hline 1771 (willow) & $\mathrm{X}$ & & & \\
\hline 1787 (onion) & $\mathrm{X}$ & & & \\
\hline 2336 (onion) & $\mathrm{X}$ & & & \\
\hline 2337 (onion) & $\mathrm{X}$ & & & \\
\hline 2338 (onion) & $\mathrm{X}$ & & & \\
\hline tabaci ${ }^{\mathrm{T}}$ & $\mathrm{X}$ & & & \\
\hline tagetis $^{\mathrm{T}}$ & $\mathrm{X}$ & & & \\
\hline tomato $^{\mathrm{T}}$ & & $\mathrm{X}$ & & \\
\hline 2545 & & $\mathrm{X}$ & & \\
\hline 2546 & & $\mathrm{X}$ & & \\
\hline$u l m i^{\mathrm{T}}$ & $\mathrm{X}$ & & & \\
\hline viburni $^{\mathrm{T}}$ & $\mathrm{X}$ & & & \\
\hline
\end{tabular}

${ }^{a}$ Inoculations were performed by infiltration of a $10^{8}$-bacteria-per-ml suspension under the flower stem epidermis.

$\mathrm{b} \mathrm{T}=$ type strain of the pathovar.
Pseudomonas strains tested, which induced either a HR on leek or no reaction at all. Leek strains were only pathogenic on leek. Therefore, leek strains could constitute a new pathovar of $P$. syringae. We propose to name the new pathovar as $P$. syringae pv. porri, pv. nov.

The symptoms caused by leek strains are distinctive. The disease affects young tissues of actively growing plants. Owing to the anatomy of monocotyledons, foliar spots spread in longitudinal stripes and the leaves typically become sickle-shaped. After an initial deep-green water-soaked phase, lesions turn yellow to orange. On flower stems, lesions enlarge to girdle the stem. Other phytopathogenic bacteria have been described on leek. Erwinia sp. stopped growth of the plant and reduced seed production (30). E. carotovora subsp. carotovora and $P$. fluorescens were isolated from rotted leeks (10). The former pathogen rotted leek during summer, while the latter organism caused disease under mild temperatures and high relative humidity. In our laboratory, pectinolytic Erwinia sp. and P. fluorescens were sometimes isolated as secondary invaders from lesions initially produced by $P$. syringae pv. porri. In contrast with the opportunistic Erwinia and P. fluorescens, $P$. syringae pv. porri was preferentially pathogenic on young tissues.

During several surveys of leek-production areas, saprophytic $P$. syringae-like strains could be isolated as opportunistic bacteria accompanying leek pathogens. The saprophytes were unequivocally distinguished from $P$. syringae pv. porri on the basis of their positive response in gelatinase, esculin, erythritol, inositol, and lactate tests; negative response in tyrosine and homoserine tests; and failure to react with POR antiserum; as well as pathogenicity to leek. The preceding tests are advised for routine identification of pv. porri. In our experience, no more than one of these tests varied for a given strain.

A few of the leek strains tested had been in international collections of phytopathogenic bacteria for 20 to 45 years: CFBP 1687 by Lelliott (17) in the United Kingdom, CFBP 752 in France, and CFBP 1770 in New Zealand. These three strains were listed as $P$. syringae strains isolated from leek and were included in pv. syringae when the pathovar classification was created (33). One may speculate that other groups of strains isolated from specific hosts may be separated from pv. syringae as more knowledge accumulates about their properties, especially pathogenicity. For instance, onion strains, so far only reported in Japan, might deserve a similar status change. Onion strains differ from leek strains on the basis of some physiological characters, serotype, and pathogenicity to various Allium spp. Onion strains also differ greatly from pv. syringae strains by many biochemical criteria (protease, esculin, mannose, sorbitol, and lactate tests, which are negative). Therefore, Japanese onion strains may also be classified in a specific pathovar (11).

TABLE 4. DNA relatedness of nine leek strains and the type strains of Pseudomonas syringae, $P$. savastanoi, and pathotype strain of $P$. syringae pv. tomato

\begin{tabular}{|c|c|}
\hline Unlabelled DNA of CFBP strains $^{\mathrm{a}}$ & $\begin{array}{c}\text { Relative reassociation with labeled DNA } \\
\text { of the leek isolate CFBP } 1908(\%)\end{array}$ \\
\hline \multicolumn{2}{|l|}{ Leek strains ${ }^{b}$} \\
\hline 1908 & 100 \\
\hline 2368 & 98 \\
\hline 4235 & 94 \\
\hline 1770 & 91 \\
\hline 1687 & 90 \\
\hline 2395 & 88 \\
\hline 1911 & 87 \\
\hline 2474 & 85 \\
\hline 4236 & 81 \\
\hline P. syringae pv. syringae $1392^{\mathrm{T}}$ & 45 \\
\hline P. savastanoi $\mathrm{pv}$. savastanoi $1670^{\mathrm{T}}$ & 48 \\
\hline P. syringae pv. tomato $2212^{\mathrm{T}}$ & 53 \\
\hline
\end{tabular}


The results of DNA-DNA hybridization presented here indicate that leek strains belong to a homogeneous DNA-DNA genomic group clearly separated from the type strain of the species $P$. syringae. The genomic heterogeneity of $P$. syringae has been mentioned by Pecknold and Grogan (22), who described three DNA-
DNA homology groups inside $P$. syringae. More recently, Denny et al. (4) showed that pv. tomato should be considered specifically distinct from $P$. syringae, but they did not formally propose to elevate pv. tomato to the species level. By contrast, Gardan et al. (7) reinstated pv. savastanoi as the species $P$. savastanoi including

TABLE 5. Differential assimilation of carbon sources by leek strains, pathovars of Pseudomonas syringae, and related bacteria

\begin{tabular}{|c|c|c|c|c|c|c|c|c|c|c|}
\hline \multirow[b]{2}{*}{ Host $^{\mathrm{a}}$} & \multicolumn{10}{|c|}{ Differential carbon sources (diagnostic ability coefficient) } \\
\hline & $\begin{array}{l}\text { Trigonelline } \\
\qquad(0,90)\end{array}$ & $\begin{array}{c}\text { Betaine } \\
(0,89)\end{array}$ & $\begin{array}{c}\text { Aconitate } \\
(0,84)\end{array}$ & $\begin{array}{c}\text { L-arginin } \\
(0,82)\end{array}$ & $\begin{array}{c}\text { Esculin } \\
(0,81)\end{array}$ & $\begin{array}{c}\text { Erythritol } \\
(0,77)\end{array}$ & $\begin{array}{c}d l \text {-OH-butyrate } \\
(0,66)\end{array}$ & $\begin{array}{c}d \text {-xylose } \\
(0,59)\end{array}$ & $\begin{array}{c}\text { Sorbitol } \\
(0,57)\end{array}$ & $\begin{array}{c}\text { D-alanin } \\
(0,34)\end{array}$ \\
\hline Phenon 5 (28 leek strains) & - & - & - & - & - & - & - & + & + & + \\
\hline \multicolumn{11}{|l|}{ Other phenons ${ }^{\mathrm{b}}$} \\
\hline 1 (four pathovars) & - & + & + & $\mathrm{d}$ & + & + & - & + & + & + \\
\hline 2 (four pathovars) & $\mathrm{d}^{\mathrm{c}}$ & + & + & $\mathrm{d}$ & $\mathrm{d}$ & + & $\mathrm{d}$ & + & + & + \\
\hline 3 (fifteen pathovars) & + & + & + & $\mathrm{d}$ & $\mathrm{d}$ & $\mathrm{d}$ & + & + & + & + \\
\hline 4 (five pathovars) & + & + & + & + & - & - & $\mathrm{d}$ & $\mathrm{d}$ & + & $\mathrm{d}$ \\
\hline 6 (four pathovars) & + & $\mathrm{d}$ & + & + & $\mathrm{d}$ & - & d & $\mathrm{d}$ & + & $\mathrm{d}$ \\
\hline \multicolumn{11}{|l|}{ Isolated phenotypes } \\
\hline P. amygdali ${ }^{\mathrm{T}}$ & - & - & - & - & - & - & - & - & + & - \\
\hline P. cichorii $^{\mathrm{T}}$ & + & + & + & + & + & - & + & + & - & + \\
\hline P. ficuserectae ${ }^{\mathrm{T}}$ & - & + & - & - & - & - & - & - & - & + \\
\hline P. syringae pv. atropurpurea ${ }^{\mathrm{T}}$ & - & + & + & + & - & + & - & + & + & + \\
\hline P. syringae pv. avellanae ${ }^{\mathrm{T}}$ & - & + & + & + & - & - & - & - & - & + \\
\hline P. syringae pv. cannabina $^{\mathrm{T}}$ & - & + & - & + & - & - & - & - & - & - \\
\hline P. syringae pv. ciccarone ${ }^{\mathrm{T}}$ & + & - & + & + & - & - & - & + & - & + \\
\hline P. syringae pv. dendropanacis ${ }^{\mathrm{T}}$ & - & - & + & - & - & - & - & + & - & - \\
\hline P. syringae pv. eriobotryae ${ }^{\mathrm{T}}$ & + & + & + & + & + & + & - & - & + & + \\
\hline$P$. syringae pv. glycinae ${ }^{\mathrm{T}}$ & + & - & + & - & - & + & - & - & - & + \\
\hline P. syringae $\mathrm{pv}$. helianthi ${ }^{\mathrm{T}}$ & + & + & + & + & - & + & - & + & + & + \\
\hline P. syringae pv. lachrymans 1644 & + & - & + & + & + & + & + & + & + & + \\
\hline P. syringae $\mathrm{pv}$. lachrymans ${ }^{\mathrm{T}}$ & + & - & - & - & + & - & - & + & + & + \\
\hline P. syringae pv. lapsa ${ }^{\mathrm{T}}$ & + & + & + & - & + & - & - & + & + & - \\
\hline P. syringae pv. mori ${ }^{\mathrm{T}}$ & - & + & + & + & - & - & - & + & - & + \\
\hline P. syringae pv. morsprunorum ${ }^{\mathrm{T}}$ & + & - & + & + & + & + & - & + & + & + \\
\hline P. syringae $\mathrm{pv}$. oryzae $\mathrm{T}^{\mathrm{T}}$ & - & + & + & + & + & + & + & + & + & + \\
\hline$P$. syringae $\mathrm{pv}$. persicae ${ }^{\mathrm{T}}$ & - & - & + & + & - & - & + & + & + & + \\
\hline P. syringae pv. phaseolicola ${ }^{\mathrm{T}}$ & + & + & + & + & - & - & - & - & - & + \\
\hline P. syringae pv. savastanoi ${ }^{\mathrm{T}}$ & + & + & - & + & - & - & - & - & - & + \\
\hline P. syringae pv. sesami ${ }^{\mathrm{T}}$ & + & + & + & - & - & + & + & + & - & - \\
\hline P. syringae pv. syringae ${ }^{\mathrm{T}}$ & + & + & + & - & + & + & + & - & + & + \\
\hline P. syringae pv. tremae ${ }^{\mathrm{T}}$ & - & - & - & - & - & - & - & - & - & - \\
\hline P. syringae $\mathrm{pv}$. ulmi $^{\mathrm{T}}$ & - & - & - & - & - & + & - & - & - & + \\
\hline P. syringae pv. viburni ${ }^{\mathrm{T}}$ & - & - & + & + & - & + & - & + & + & + \\
\hline P. viridiflava ${ }^{\mathrm{T}}$ & + & + & + & + & + & + & + & + & + & + \\
\hline
\end{tabular}

$\mathrm{a}_{\mathrm{T}}=$ type strain of the species or the pathovar.

${ }^{\mathrm{b}}$ Figure 2 contains the list of pathovars of the six phenons.

${ }^{\mathrm{c}} \mathrm{d}=$ at least one differing strain.

TABLE 6. Conventional biochemical tests that differentiate leek strains from serologically and taxonomically related Pseudomonas syringae strains

\begin{tabular}{|c|c|c|c|c|c|c|c|c|c|c|c|c|c|c|}
\hline \multirow[b]{2}{*}{ Pathovar } & \multirow[b]{2}{*}{ CFBP strain } & \multirow[b]{2}{*}{ O-serogroup ${ }^{a}$} & \multicolumn{12}{|c|}{ Tests $^{b}$} \\
\hline & & & GEL & CAS & ESC & TYR & PP5 & ERT & MNO & INT & SBT & LCA & DTA & HSR \\
\hline porri (40 strains) & & POR & $+1^{\mathrm{c}}$ & - & - & +1 & - & - & + & - & $(+)$ & - & - & $(+)$ \\
\hline coronafaciens & $2216^{\mathrm{T}}$ & SYR2 & - & - & + & - & + & + & + & + & + & - & - & - \\
\hline atropurpurea & $2340^{\mathrm{T}}$ & SYR2 & +1 & - & - & +1 & - & + & + & + & + & - & - & - \\
\hline syringae (maize) & 1685 & SYR2 & + & + & + & - & - & + & + & + & + & + & - & - \\
\hline syringae (wheat) & 1767 & SYR2 & + & + & + & - & - & + & + & + & + & + & - & - \\
\hline syringae (willow) & 1771 & SYR2 & + & + & + & +1 & - & $(+)$ & + & $(+)$ & + & + & - & - \\
\hline tomato & 2545 & PERSAVTOM2 & +1 & + & +1 & - & + & - & + & + & - & - & + & - \\
\hline cannabina & $2341^{\mathrm{T}}$ & PERSAVTOM2 & - & - & - & + & + & - & + & - & - & - & - & - \\
\hline garcae & $1634^{\mathrm{T}}$ & PERSAVTOM2 & + & + & + & + & - & $(+)$ & + & + & + & - & - & - \\
\hline papulans & $1754^{\mathrm{T}}$ & PERSAVTOM2 & +1 & - & + & - & - & $(+)$ & + & $(+)$ & $(+)$ & + & - & - \\
\hline syringae (lilac) & $1392^{\mathrm{T}}$ & PERSAVTOM2 & + & + & + & - & - & $(+)$ & + & + & + & + & - & - \\
\hline syringae (bean) & 1764 & PERSAVTOM2 & + & + & + & - & - & + & + & + & + & + & - & - \\
\hline viburni & $1702^{\mathrm{T}}$ & DEL & - & - & - & - & - & - & + & $(+)$ & $(+)$ & - & - & - \\
\hline syringae (onion) & 1787 & DEL & - & - & - & +1 & - & - & - & + & - & - & - & - \\
\hline syringae (onion) & 2336 & DEL & - & - & - & +1 & - & $(+)$ & - & $(+)$ & - & - & - & - \\
\hline syringae (onion) & 2337 & DEL & - & - & - & + & - & - & - & $(+)$ & - & - & - & - \\
\hline syringae (onion) & 2338 & DEL & +1 & - & - & +1 & - & $(+)$ & - & $(+)$ & - & - & - & - \\
\hline delphinii & $2215^{\mathrm{T}}$ & DEL & +1 & + & + & + & - & + & + & + & $(+)$ & - & - & - \\
\hline
\end{tabular}

a O-serogroups according to Saunier et al. (26).

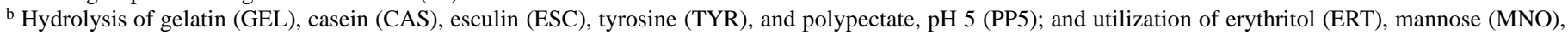
inositol (INT), sorbitol (SBT), lactate (LCA), D-(-)-tartrate (DTA), and homoserine (HSR).

${ }^{c}+=$ positive for $>90 \%$ strains in 8 days, $+1=$ light positive, $(+)=$ positive in 9 to 15 days, and $-=$ negative for $>90 \%$ strains in 15 days . 
pv. savastanoi, pv. glycinea, and pv. phaseolicola. Actually, four major DNA-DNA homology groups, represented by the pathotypes syringae, savastanoi, tomato, and porri, were circumscribed within 50 of the $P$. syringae pathovars (9). Unfortunately, no distinguishing physiological and phenotypical characteristics could be deduced for the genomic groups. This lack of criteria for differentiation was not in accordance with the definition of a bacterial species (31). Accordingly, the genomic groups have not yet converted into formal species. Until they can be differentiated by biochemical tests, the status of pathovars within $P$. syringae should be kept. This is the reason why we do not propose to elevate pv. porri to a species rank.

Description of $\boldsymbol{P}$. syringae pv. porri, pv. nov. $P$. syringae pv. porri adjective from porrum, the Latin name of leek (A. porrum).

Cells are Gram-negative, motile with several polar flagella, and obligate aerobes with oxidative metabolism of glucose. Slow growth occurs on YPDA and on King's medium B, producing colonies of 1.5 and $0.5 \mathrm{~mm}$, respectively, after 3 days of incubation. Bacteria produce green fluorescent pigment on King's medium B. They are oxidase negative, levan positive, nonpectinolytic, arginine dihydrolase negative, and give a HR on tobacco.

$P$. syringae pv. porri is positive for tyrosinase activity and for utilization of mannose, mannitol, and malonate; delayed positive for hydrolysis gelatin and for utilization of sorbitol and homoserine; and negative for utilization of casein, esculin ( $\mathrm{pH} 5.5)$, polygalacturonate, erythritol, inositol, DL-lactate, D-(-)-tartrate, and L-(+)-tartrate. Differential growth on the following carbon sources separates $P$. syringae pv. porri from the other $P$. syringae pathovars and related bacteria: assimilation of D-xylose, sorbitol, and D-alanine; and no assimilation of trigonelline, betaine, aconitate, L-arginine, esculin, erythritol, and $d l$-hydroxybutyrate.

Bacteria are in O-serogroup POR, and the flagella belong to the serotype H1. Bacteria display moderate INA (about $80 \%$ strains are INA positive at $-5^{\circ} \mathrm{C}$ ).

Pathogenic strains belonging to pv. porri specifically cause watersoaked spots on leek.

Strain 1908 is designated as the holopathotype of pv. porri. It was deposited, along with five other strains in three international collections: CFBP $1908^{\mathrm{T}}, 752,1911,1912,2360$, and 2366; NCPPB 3364, 3365, 3366, 3367, 3368, and 3369; and ICMP 8961, 8960, $8962,8963,8964$, and 8965.

\section{LITERATURE CITED}

1. Ayers, S. H., Rupp, P., and Johnson, W. T. 1919. Study of the alkaliforming bacteria in milk. U.S. Dep. Agric. Bull. 782.

2. Brenner, D. J., McWorter, A. C., Leete Knutson, J. K., and Steigerwalt, A. G. 1982. Escherichia vulneris: A new species of Enterobacteriaceae associated with human wounds. J. Clin. Microbiol. 15:1133-1140.

3. Crosa, J. H., Brenner, D. J., and Falkow, S. 1973. Use of a single-strand specific nuclease analysis of bacterial and plasmid deoxyribonucleic acid homo and heteroduplexes. J. Bacteriol. 115:904-911.

4. Denny, T. P., Gilmour, M. N., and Selander, R. K. 1988. Genetic diversity and relationships of two pathovars of Pseudomonas syringae. J. Gen. Microbiol. 134:1949-1960.

5. Descamps, P., and Véron, M. 1981. Une méthode de choix des caractères d'identification basée sur le théorème de Bayes et la mesure de l'information. Ann. Microbiol. Inst. Pasteur 132B:157-170.

6. Dye, D. W., Bradbury, J. F., Goto, M., Hayward, A. C., Lelliott, R. A., and Schroth, M. N. 1980. International standards for naming pathovars of phytopathogenic bacteria and a list of pathovar names and pathotype strains. Rev. Plant Pathol. 59:163-168.

7. Gardan, L., Bollet, C., Abu-Ghorrah, M., Grimont, F., and Grimont, P. A. D. 1992. DNA relatedness among the pathovar strains of Pseudomonas syringae subsp. savastanoi Janse (1982) and proposal of Pseudomonas savastanoi sp. nov. Int. J. Syst. Bacteriol. 42:606-612.

8. Gardan, L., Shafik, H., Belouin, S., Broch, R., Grimont, F., and Grimont, P. A. D. DNA relatedness among pathovars of Pseudomonas syringae. Int. J. Syst. Bacterial. In press.

9. Gardan, L., Shafik, H., and Grimont, P. A. D. 1997. DNA relatedness among pathovars of Pseudomonas syringae and related bacteria. Pages 445-448 in: Pseudomonas syringae pathovars and related pathogens. Kluwer Academic Publishers, Dordrecht,the Netherlands.
10. Garibaldi, A., and Tamietti, G. 1977. Etiology and epidemiological aspects of bacterial soft rot of leeks in Liguria. Phytopathol. Medit. 16:27-29.

11. Goto, M. 1972. Bacterial leaf spot of onions in Japan. Plant Dis. Rep. 56:490-493.

12. Guillorit-Rondeau, C., Malandrin, L., and Samson, R. 1996. Identification of two serological flagellar types (H1 and H2) in Pseudomonas syringae pathovars. Eur. J. Plant Pathol. 102:99-104.

13. Hale, C. N. 1975. Bacteriosis of leek in New Zealand. J. Agric. Res. 18: 251-254.

14. Hirano, S. S., Maher, E. A., Kelman, A., and Upper, C. D. 1978. Ice nucleation activity of fluorescent plant pathogenic pseudomonads. Pages 717-724 in: Proc. Int. Conf. Plant Pathogenic Bacteria, 4th. Institut National de la Recherche Agronomique, Angers, France.

15. Janse, J. D. 1982. Enkele nieuw waargenomen aantastingen van Pseudomonas syringae. Versl. Meded. Plantenziektenk. Dienst 158(Jaarboek 1981):34-35

16. Koike, S. T., Henderson, D. M., Barak, J. D., and Gilbertson, R. L. 1997. A leaf blight disease of leek in California caused by Pseudomonas syringae, and association of the pathogen with seed. (Abstr.) Phytopathology 87:S53.

17. Lelliott, R. A. 1952. A new bacterial disease of leeks. Plant Pathol. $1: 84-85$.

18. Lelliott, R. A., Billing, E., and Hayward, A. C. 1966. A determinative scheme for the fluorescent plant pathogenic Pseudomonas. J. Appl. Bacteriol. 29:470-489.

19. Lelliott, R. A., and Stead, D. E., eds. 1987. Methods for the Diagnosis of Bacterial Disease of Plants. Blackwell Scientific Publications, Oxford.

20. Palleroni, N. J. 1984. Family I Pseudomonadaceae. Genus I Pseudomonas. 6 Pseudomonas syringae. Pages 168-172 in: Bergey's Manual of Systematic Bacteriology. Williams and Wilkins, Baltimore, MD.

21. Paulin, J. P., and Luisetti, J. 1978. Ice nucleation activity among phytopathogenic bacteria. Pages 725-731 in: Proc. Int. Conf. Plant Pathogenic Bacteria, 4th. Institut National de la Recherche Agronomique, Angers, France.

22. Pecknold, P. C., and Grogan, R. G. 1973. Deoxyribonucleic acid homology groups among phytopathogenic Pseudomonas species. Int. J. Syst. Bacteriol. 23:111-121.

23. Samson, R., and Benjama, A. 1984. Physiological and serological identification of Pseudomonas syringae pv. porri pathogenic to Allium porrum. Pages 52-53 in: Proc. Working Group Pseudomonas syringae pathovars, 2nd. The Hellenic Phytopathological Society, Athens, Greece.

24. Samson, R., Poutier, F., and Rat, B. 1981. Une nouvelle maladie du poireau: la graisse bactérienne à Pseudomonas syringae. PHM Rev. Hortic. 219:20-23.

25. Samson, R., and Saunier, M. 1987. Désignation de références sérologiques pour six sérogroupes de pathovars de Pseudomonas syringae sur la base de leur lipopolyoside. Bull. OEPP (Organ. Eur. Mediterr. Prot. Plant.)/EPPO (Eur. Mediterr. Plant Prot. Organ.) Bull. 17:165-171.

26. Saunier, M., Malandrin, L., and Samson, R. 1996. Distribution of Pseudomonas syringae pathovars into twenty-three O-serogroups. Appl. Environ. Microbiol. 62:2360-2374.

27. Schroth, M. N., Hildebrand, D. C., and Sands, D. C. 1988. Pseudomonas. Pages 60-80 in: Laboratory Guide for Identification of Plant Pathogenic Bacteria. 2nd ed. N. W. Schaad, ed. The American Phytopathological Society, St. Paul, MN.

28. Sneath, P. H. A., and Sokal, R. R. 1973. Numerical Taxonomy. The Principles and Practice of Numerical Classification. W. H. Freeman, San Francisco, CA.

29. Varvaro, L. 1983. Una batteriosi del porro Allium porrum in Puglia. Phytopathol. Medit. 22:86-88.

30. Vitanov, M. 1971. Bacterial rot of leek seed-plants. (Abstr. 529) Rev. Plant Pathol. 51:529.

31. Wayne, L. G., Brenner, D. J., and Colwell, R. R. 1987. Report of the ad hoc committee on reconciliation of approaches to bacterial systematic. Int. J. Syst. Bacteriol. 37:463-464.

32. Young, J. M., Bradbury, J. F., Davis, R. E., Ercolani, G. L., Hayward, A. C., and Vidaver, A. K. 1991. Nomenclatural revisions of plant pathogenic bacteria and list of names 1980-1988. Rev. Plant Pathol. 70:211-221

33. Young, J. M., Dye, D. W., Bradbury, J. F., Panagopoulos, C. G., and Robbs, C. F. 1978. A proposed nomenclature and classification for plant pathogenic bacteria. N.Z. J. Agric. Res. 21:153-177.

34. Young, J. M., Saddler, G. S., Takikawa, Y., De Boer, S. H., Vauterin, L., Gardan, L., Gvozdyak, R. I., and Stead, D. E. 1996. Names of plant pathogenic bacteria 1864-1995. Rev. Plant Pathol. 75:721-763. 